\title{
Phenetic studies on randomly amplified polymorphic DNA-polymerase chain reaction-variability of four geographical populations of Lutzomyia whitmani (Diptera: Psychodidae) in Brazil
}

\author{
Estudos fenéticos de variabilidade de polimorfismos de DNA amplificados ao acaso pela \\ reação em cadeia da polimerase em quatro populações geográficas \\ de Lutzomyia whitmani (Diptera: Psychodidade) no Brasil
}

Carina Margonari de Souza ${ }^{1}$, Consuelo Latorre Fortes-Dias ${ }^{2}$, Pedro Marcos Linardi ${ }^{3}$ and Edelberto Santos Dias ${ }^{1}$

\begin{abstract}
Previous evaluation of the genetic variability of four biogeographical populations of Lutzomyia whitmani from known foci of cutaneous leishmaniasis in Brazil demonstrated two main spatial clusters: Corte de Pedra-BA, Ilhéus-BA and Serra de Baturité-CE in the first cluster, and Martinho Campos-MG in the second. Further analysis showed a high degree of homogeneity in Corte de Pedra population but not in the others, which presented a significant percentage of specimens displaced from their phenon of origin (discrepant individuals). In the present work we analyzed the frequencies of association coefficients in the matrixes of similarity per population of Lutzomyia whitmani from both sexes and the general phenograms obtained, in a more detailed study of those discrepant specimens. Populational stability was observed for Corte de Pedra population, whereas the three remaining populations showed varying degrees of heterogeneity and different displacements according to sex. Our results strongly suggested the existence of a genetic flow between the lineages North- South/North-East and Ilhéus/ Serra do Baturité of Lutzomyia whitmani.
\end{abstract}

Key-words: Lutzomyia whitmani. Sand fly. Genetic variability. RAPD-PCR.

\section{RESUM0}

Uma avaliação prévia da variabilidade genética de quatro populações biogeográficas de Lutzomyia whitmani oriundas de focus conhecidos de leishmaniose cutânea no Brasil, evidenciou 2 agrupamentos espaciais principais: Corte de Pedra (BA), Ilhéus ( BA) e Serra de Baturité (CE) no primeiro grupo, e Martinho Campos (MG) em um segundo. 0 aprofundamento da análise acusou um alto grau de homogeneidade na população de Corte de Pedra mas não nas outras, nas quais uma porcentagem significativa de espécimens deslocou-se do seu feno de origem (indivíduos discrepantes). Neste trabalho analisamos as freqüências dos coeficientes de associação nas matrizes de similaridade por população de Lutzomyia whitmani, de ambos os sexos, e o fenograma geral obtido, em um estudo mais detalhado daqueles espécimens discrepantes. Para Corte de Pedra foi observada estabilidade populacional, enquanto as outras três populações restantes mostraram graus de heterogeneidade variáveis e deslocamentos distintos, de acordo com o sexo dos indivíduos. Nossos resultados sugerem fortemente a existência de um fluxo genético entre as linhagens Norte-Sul/Norte-Leste e Ilhéus/Serra do Baturité de Lutzomyia whitmani.

Palavras-chaves: Lutzomyia whitmani. Febotomíneo. Variabilidade genética. Reação em cadeia da polimerase.

1. Laboratório de Leishmanioses do Centro de Pesquisas René Rachou da Fundação Oswaldo Cruz, Belo Horizonte, MG; 2. Centro de Pesquisa e Desenvolvimento da Fundação Ezequiel Dias, Belo Horizonte, MG; 3. Departamento de Parasitologia da Universidade Federal de Minas Gerais, Belo Horizonte, MG, Brasil ( CNPq fellow) Work supported by: FIOCRUZ (0250.250.200); FAPEMIG (CBB 1223/95); CNPq (521712/93-9)

Address to: Dr. Edelberto Santos Dias. Laboratório de Leishmanioses/Centro de Pesquisas René Rachou/FIOCRUZ, Av. Augusto de Lima 1715, 30190-002 Belo Horizonte, MG.

Tel: 5531 3295-3566; Fax: 5531 3295-3115.

e-mail: edel@cpqrr.fiocruz.br

Recebido para publicação em 8/8/2003

Aceito em 9/12/2003 
Lutzomyia whitmani (Antunes \& Coutinho, 1939) is a phlebotomine sand fly in the subgenus Nyssomyia that has been prevalent at Brazilian foci of cutaneous leishmaniasis in the state of Minas Gerais ${ }^{1315}$, Bahia ${ }^{414}$ and Ceará ${ }^{317}{ }^{18}$ It has been incriminated as a vector of human American cutaneous leishmaniasis, following the finding of specimens naturally infected with Leishmania parasites from the braziliensis complex ${ }^{4}$, associated with human cases of the disease. Furthermore, a high anthropophilic behavior has been described for this sand fly species ${ }^{38916}$.

Several studies have suggested that $\mathrm{L}$ whitmani is, in fact, a complex of species. Phylogenetic analysis of morphometric, biochemical and molecular characters of $\mathrm{L}$ whitmani indicated that there are, at least, three to four distinct mitochondrial lineages in Brazil ${ }^{11} 1920$. The first lineage is an Amazonian form, strictly silvatic, described from the northeast and southeast regions of the Amazon river, state of Pará. A second form was found in the northeastern Atlantic Forest zone, including the species type locality, distinguishable from the third group of haplotypes, which is located in the drier interior of Brazil ( northsouth group). Afourth lineage has been more recently described in the state of Rondônia, based on phylogenetic studies of mitochondrial DNA. An overall analysis showed that those lineages from forested regions (Rondônia, Amazonian and Northeastern) form a clade totally separated from the northsouth lineage.

In a previous work, we analyzed the genetic variability of four geographical populations of L whitmani in Brazil by randomly amplified polymorphic DNA-polymerase chain reaction ${ }^{12}$. The great majority of individuals fitted into the interpopulational phenograms according to their region of origin. However, a small discrepant group displaced from their region of origin was noted. The objective of the current work was to focus on those specimens unlinked to the phenon of origin.

\section{MATERIAL AND METHODS}

Phlebotomine. Sand flies were captured atnightby Shannon ${ }^{24}$ and $\mathrm{CDC}^{26}$ traps at the Brazilian municipalities of Corte de Pedra, Bahia $\left(13^{\circ} 26^{\prime} 23^{\prime \prime} \mathrm{S}, 39^{\circ} 39^{\prime} 36^{\prime \prime} \mathrm{W}\right)$; Ilhéus, Bahia $\left(14^{\circ} 47^{\prime} 2^{\prime \prime} \mathrm{S}\right.$,

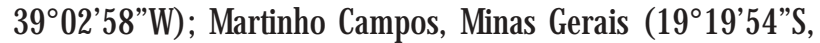
$\left.45^{\circ} 14^{\prime} 13^{\prime \prime} \mathrm{W}\right)$ and Serra de Baturité, Ceará (04 ${ }^{\circ} 19^{\prime} 43^{\prime \prime} \mathrm{S}$, $38^{\circ} 53^{\prime} 05^{\prime \prime} \mathrm{W}$ ). The traps were mounted at 5:00 p.m. and taken down at 7:00 a.m. the next day, for 5-7 consecutive days per region. In the laboratory, female sand flies were fed on non-infected hamsters (Mesocricetus auratus). After 24h they were isolated into individual containers until oviposition ${ }^{14}$ after which they were mounted on microscope slides in Berlese medium ${ }^{27}$ and identified according to Young and Duncan ${ }^{30}$. Eggs from 500 females identified as L whitmani were combined, transferred to new containers and incubated in a humid chamber at $27^{\circ} \mathrm{C}$ until eclosion. We obtained aproximately 200 specimens of $\mathrm{L}$ whitmani per population in Fl, from which 50 males and 50 females were frozen and stored in liquid nitrogen for later use.
DNA extraction. Fifteen specimens of L. whitmani of each sex and population were randomly selected from the frozen stock. Each specimen was macerated in a microtube using a plastic pestle, followed by addition of $50 \mu \mathrm{l}$ of lysis buffer ( $100 \mathrm{mM}$ TRIS-HCl, $100 \mathrm{mMNaCl}, 25 \mathrm{mM}$ EDTA, 0.5\% SDS, pH8.0) and macerated again. Genomic DNA extraction was performed as described by Ausubel et $\mathrm{al}^{2}$. The final pellet was ressuspended in $20 \mu \mathrm{l}$ of TE 1X. Ten microliters were used for estimation of DNA concentration and purity by optical readings at 280 and $260 \mathrm{~nm}$ in a spectrophotometer and then discarded. The remaining $10 \mu \mathrm{l}$ were stored at $4^{\circ} \mathrm{C}$ until use.

DNA amplification. DNA was amplified by RAPD-PCR ${ }^{28} 29$ in a thermocycler ( Perkin-Elmer 2400) in a total reaction volume of $60 \mu$ l. The reaction mixture was prepared as follows: $12 \mu \mathrm{l}$ of PCR buffer ( $100 \mathrm{mM}$ TRIS- $\mathrm{HCl}, 500 \mathrm{mM} \mathrm{KCl}, 25 \mathrm{mM} \mathrm{MgCl}$, $\mathrm{pH}$ 8.3), 9.6 $\mu \mathrm{l}$ dNTPs ( $10 \mathrm{mM}$ each), $8 \mu \mathrm{l}$ of a random primer (70ng) and 18.4 $\mu$ l of ultrapure water. Six microliters of DNA (2ng) were added per reaction and the microtubes incubated at $94^{\circ} \mathrm{C}$ for $1 \mathrm{~min}$. After addition of $6 \mu \mathrm{l}(1.5 \mathrm{U})$ of diluted Taq polymerase (Perkin Elmer), the amplification reaction was performed for 45 cycles of $30 \mathrm{~s}$ at $94^{\circ} \mathrm{C}, 30 \mathrm{~s}$ at $34^{\circ} \mathrm{C}$ and $1 \mathrm{~min}$ at $72^{\circ} \mathrm{C}$. The random primers were: OPG09 (CTGACGTCAC), OPG12 (CAGCTCACGA), 3302 (CTGATGCTAC) or 3303 (TCACGATGCA) . A negative (no DNA) and a positive (lambda DNA) control were used in all amplifications.

DNA PAGE. Twelve microliters of the amplification products were analyzed by $4 \%$ PAGE ( $10 \times 8.5 \times 1.5 \mathrm{~cm})$ in TBE buffer for $10 \mathrm{~min}$ at $50 \mathrm{~V}$ followed by $90 \mathrm{~min}$ at $80 \mathrm{~V}$, and developed by silver staining ${ }^{23}$. $\phi X 174 \mathrm{RF}$ DNA/HaeIII fragments and $1 \mathrm{~Kb}$ ladder (Gibco-BRL) were used as size markers. Gels were documented by a Polaroid Camera (Kodak) or an Eagle Eye System ( Stratagene, La Jolla, US).

Data analysis. The PAGE fragments selected for analysis were the most consistently visible in all gels. The presence or absence of a given gel band was codified as 1 or 0 , respectively, and used in the construction of a series of matrixes taxon/ character. Association coefficients were determined following Dice $^{7}$ and the phenograms were constructed by unweighted pair-group method analysis (UPGMA) ${ }^{25}$ through the NTSYS - pc version 2.0 software ${ }^{22}$.

\section{RESULTS}

Absolute frequencies of the association coefficients derived from the matrixes of similarity including both sexes were analyzed per region of origin showing association coefficients in the range $0.47-0.60,0.53-0.86,0.39-0.77$ and $0.53-0.84$ for Corte de Pedra (BA), Ilhéus (BA), Martinho Campos (MG) and Serra de Baturité (CE), respectively ( Figure 1). In general, a high variability in frequency and a persistent modal discontinuity were observed in all cases. It is worth noting the oscillation in the profile of frequencies for Martinho Campos population ( 0.50 , $0.53,0.57,0.59,0.61$ and 0.69 ) at the highest frequency modes $(0.52,0.56,0.58$ and 0.60$)$. 


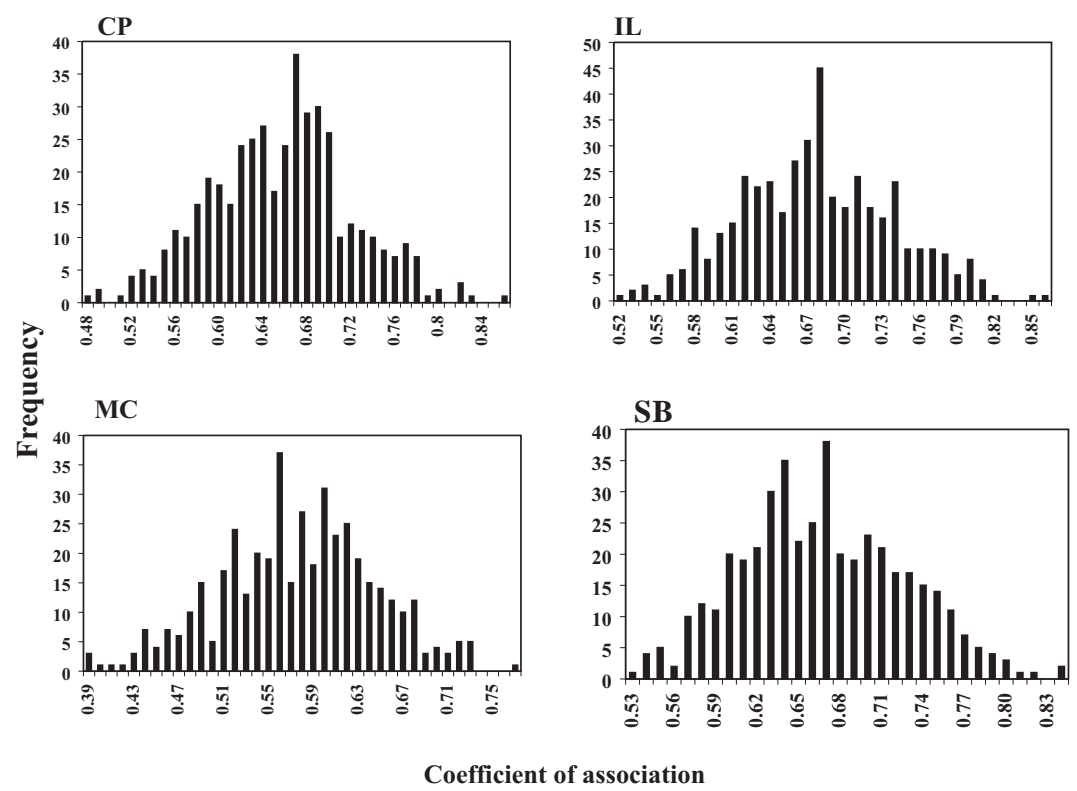

Figure 1 - Frequencies of association coefficients in the matrixes of similarity per population of Lutzomyia whitmani from both sexes. Origin of populations- CP: Corte de Pedra/MG, IL: Ilhéus/BA, MC: Martinho Campos/MG and SB: Serra de Baturité/CE.

Despite the high variability of association coefficients in the populations, the great majority of specimens was grouped according to their region of origin, in the interpopulational analysis per sex ( Figures 2 and 3). However, a discrepant group was clearly formed by a limited number of specimens. For the females, it was composed of specimens numbered 301, 322 and 325 from Serra de Baturité and 18, 19, 20, 22, and 23 from Martinho Campos (Figure 2). Another discrepant group was observed for the males, comprising specimens 358 from Serra de Baturité, 275 and 280 from Ilhéus (BA) and 52 and 81 from Martinho Campos ( Figure 3). Analysis of the displacement of similarities for the discrepant groups is summarized in Table 1.

\section{DISCUSSION}

The histogram profiles pointed to a variable range of association coefficients for the populations under study ( Figure 1). Modal discontinuity was a common point, indicating the existence of a high level of intrapopulational genetic variability as previously described ${ }^{12}$. Intrapopulational variability associated with a low value of the highest frequency coefficient (0.56) distinguished Martinho Campos population from the others. The persistent discontinuity in the association coefficients ( 0.65) in the histograms of Corte de Pedra, Ilhéus, and Serra de Baturité might represent an aspect of similarity between these three populations, if one considers the positioning of this discontinuity in the same mode.

The phenon lines (equivalent to the mean of similarities among all the specimens analyzed) in the interpopulational phenograms of males and females (Figures 2 and 3 ) denote the greater homogeneity of Corte de Pedra and Serra de Baturité populations. All the individuals in these populations were grouped according to their region of origin. Females from Ilhéus formed a phenon including the discrepant group ( Figure 2)

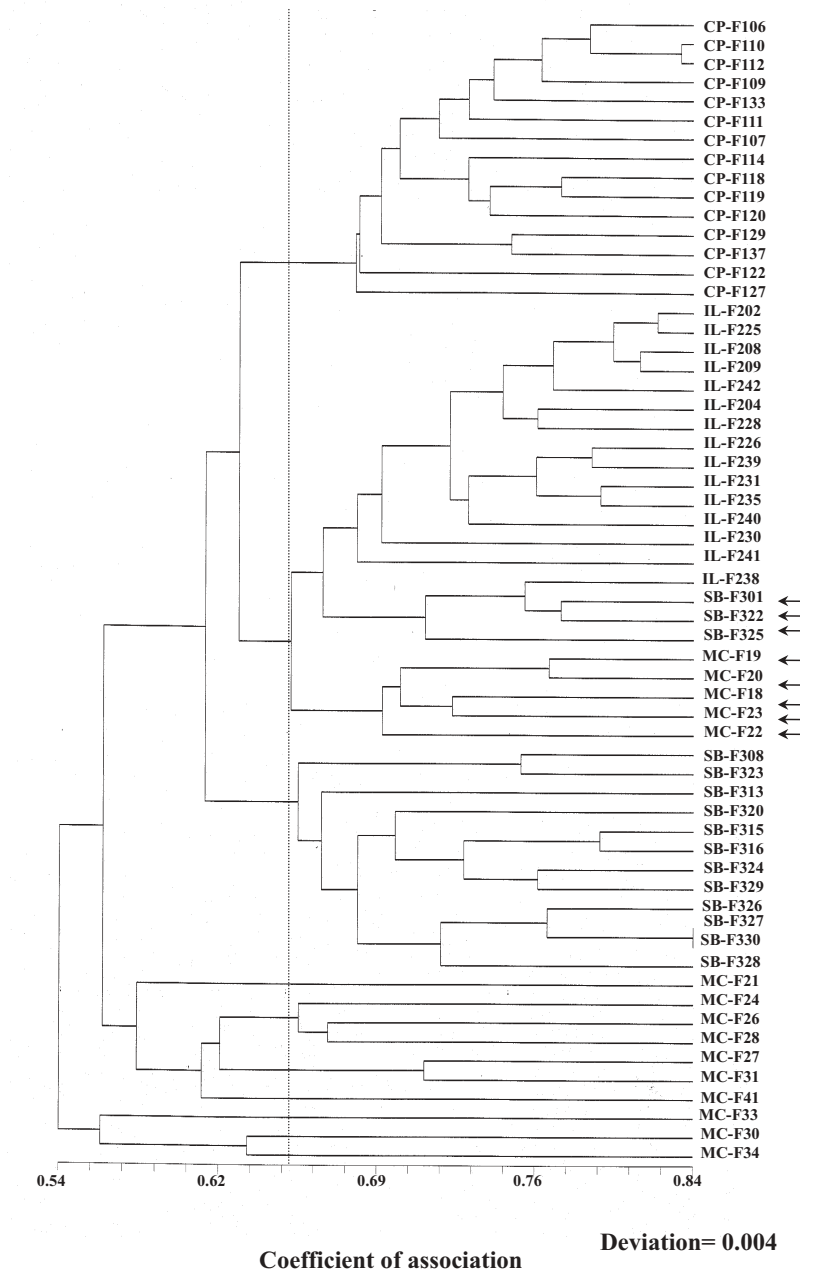

Figure 2 - General phenogram for females of Lutzomyia whitmani generated by NTSYS software. Each specimen was identified by the initials of the population (CP: Corte de Pedra/MG; IL: Ilhéus/BA; MC: Martinho Campos/MG; SB: Serra de Baturité/ $\mathrm{CE}$ ) , sex ( $\mathrm{Ffor}$ female) and a three digits number. The vertical line represents the average level of similarity between all the pairs of OTU's analyzed (phenon line). 
Table 1- Percentage of specimens of L. whitmani linked in the same phenogram and displacement analysis of the discrepant group. CP: Corte de Pedra/ BA, MC: Martinho Campos/ MG, IL: Ilhéus/ BA and SB: Serra de Baturité/ CE, F- females, M- males.

\begin{tabular}{|c|c|c|c|c|c|c|c|c|c|c|c|c|c|}
\hline \multirow[t]{3}{*}{ Software } & \multirow[t]{3}{*}{ Locality } & \multicolumn{2}{|c|}{$\begin{array}{c}\text { Total number of } \\
\text { individuals analyzed }\end{array}$} & \multicolumn{4}{|c|}{ Linked individuals } & \multicolumn{4}{|c|}{$\begin{array}{l}\text { Individuals in } \\
\text { the discrepant group }\end{array}$} & \multicolumn{2}{|c|}{$\begin{array}{l}\text { Locality of displacement } \\
\text { of the discrepant group }\end{array}$} \\
\hline & & \multirow[t]{2}{*}{ F } & \multirow[t]{2}{*}{ M } & \multicolumn{2}{|r|}{$\mathrm{F}$} & \multicolumn{2}{|c|}{ M } & \multicolumn{2}{|c|}{$\mathrm{F}$} & \multicolumn{2}{|c|}{ M } & \multirow[t]{2}{*}{$\mathrm{F}$} & \multirow[t]{2}{*}{ M } \\
\hline & & & & $\mathrm{n}^{0}$ & $\%$ & $\mathrm{n}^{0}$ & $\%$ & $\mathrm{n}^{0}$ & $\%$ & $\mathrm{n}^{0}$ & $\%$ & & \\
\hline \multirow{4}{*}{ NTSYS } & $\mathrm{CP}$ & 15 & 15 & 15 & 100.0 & 15 & 100.0 & 0 & 0 & 0 & 0 & - & - \\
\hline & $\mathrm{IL}$ & 15 & 15 & 14 & 93.0 & 13 & 87.0 & 1 & 7.0 & 2 & 13.0 & SB & SB \\
\hline & MC & 15 & 15 & 10 & 67.0 & 13 & 87.0 & 5 & 33.0 & 2 & 13.0 & IL & SB \\
\hline & SB & 15 & 15 & 12 & 80.0 & 14 & 93.0 & 3 & 20.0 & 1 & 7.0 & IL & SB \\
\hline
\end{tabular}

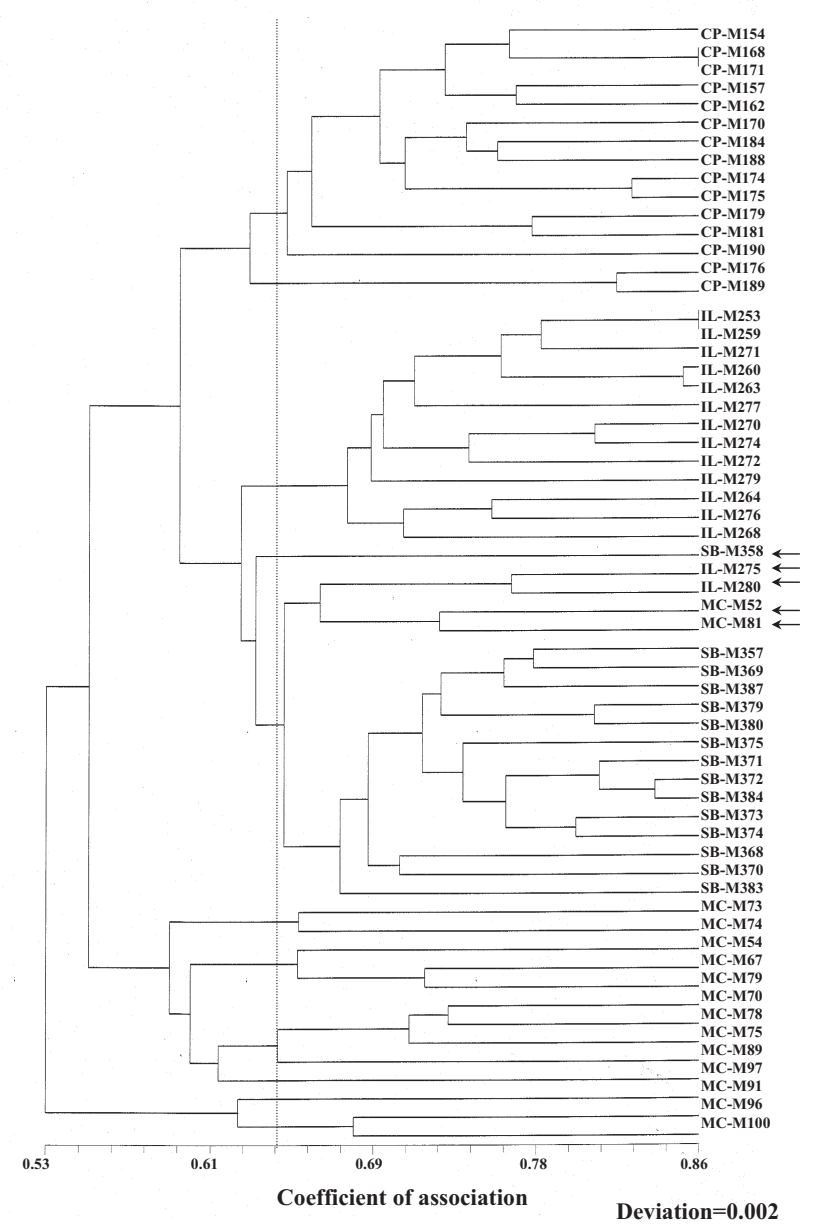

Figure 3 - General phenogram for males of Lutzomyia whitmani generated by NI-SYS software. Each specimen was identified by the initials of the population (CP: Corte de Pedra/MG; IL: Ilhéus/BA; MC: Martinho Campos/ MG; SB: Serra de Baturité/CE), sex (Mfor male) and a three digits number. The vertical line represents the average level of similarity between all the pairs of OTU's analyzed (phenon line).

evidencing the similarity between these insects. Incorporation of the discrepant group was not observed for the males from the same region ( Figure 3). Spreading of discrepant individuals from Martinho Campos population in distinct groups suggested a non-uniformity in this population for both sexes.

Further analysis of the displacement of similarities for the discrepant groups confirmed that Corte de Pedra is the most uniform population with $100 \%$ of females and males grouped

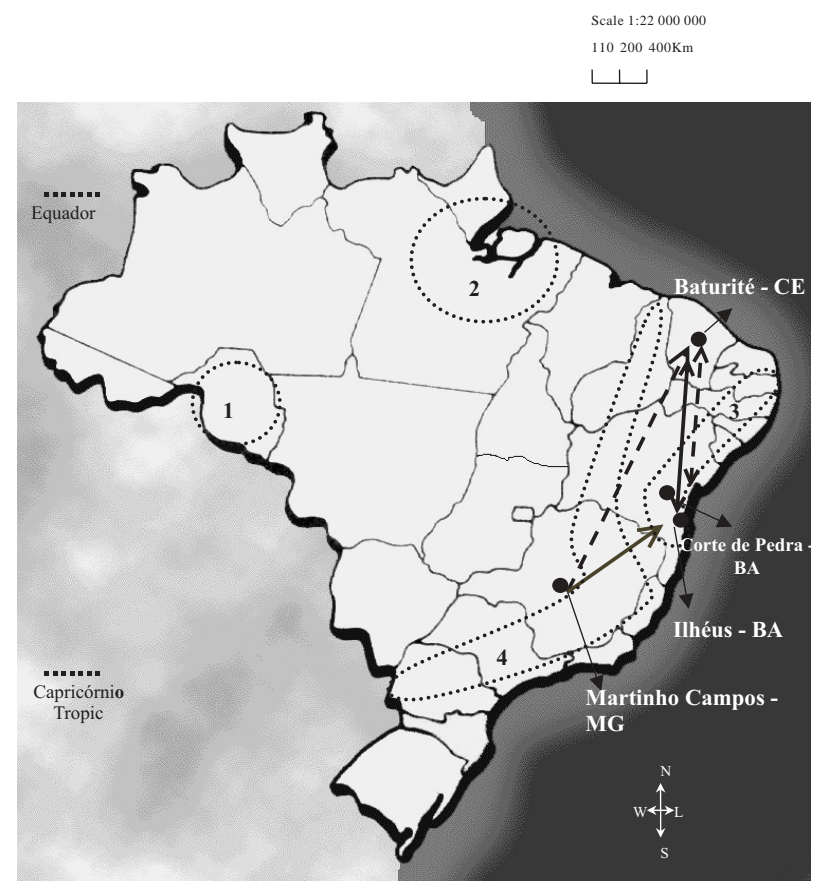

Figure 4 - Geographic distribution of the localities used for sand fly captures in Brazil, schematic representation of the Lutzomyia whitmani lineages and displacement lines of similarities for the discrepant specimens from the four populations studied. Dotted lines delimit the lineages already described- 1: State of Rondônia; 2: Amazonian; 3: Northeast; 4: North-south. Dotted and full arrows correspond to the displacement flow of similarity for males and females, respectively.

in a single phenon (Table 1). The high level of homogeneity in both sexes suggests a populational stability and perhaps a genetic isolation of this region. This hypothesis is reinforced by the overall analysis of discrepant individuals from the other regions with the Corte de Pedra phenon was never observed. The three populations remaining showed varying degree of heterogeneity and different displacements for females or males. In the first case, $93 \%$ of the specimens from Ilhéus formed a phenon while $7 \%$ suffered a displacement to the Serra de Baturité population. Martinho Campos displayed the highest heterogeneity with only $67 \%$ of specimens grouped in a characteristic phenon. Discrepant individuals (33\%) were displaced consistently towards Ilhéus group. A similar displacement was observed for discrepant females from Serra de Baturité. Differently from previously reported ${ }^{619}$. Ilhéus and Serra de Baturité populations were notgrouped into the same phenon but close to each other ${ }^{12}$. 
The discrepant females from Ilhéus population grouped consistently with Serra do Baturité (CE) phenon and vice-versa. The fact is indicative of a high degree of similarity between these two populations. The displacements observed ( Martinho Campos and Serra de Baturité towards Ilhéus and Ilhéus towards Serra do Baturité) suggest the existence of genetic flows between the lineages north-south/north-east populations and Ilhéus/Serra do Baturité ( Figure 4).

Analysis of male populations revealed aspects similar to those discussed for females. The greatmajority of specimens were grouped accordingly to their region of origin ( Figure 3). However, differently from the females, $13 \%$ of males from Martinho Campos were displaced towards Serra de Baturité instead of Ilhéus. It is most probable that Martinho Campos population belongs to the north-south lineage, which is extensively distributed in Brazil from the States of Piauí (PI) to Paraná ( $\mathrm{PR})^{2021}$. It is probable that the genetic non-uniformity of the lineage results from the existence of sympatric populations in those regions. As pointed outbefore, individuals with intermediate profiles could be explained by the occurrence of a gene flow.

In conclusion, analysis of the discrepant specimens of L whitmani suggested some gene flow among the populations under study. We believe that further studies on the susceptibility of $\mathrm{L}$ whitmani from different regions to Leishmania infection, associated with intra- and inter-lineages analyses, will help to clarify our understanding of sympatry, genetic flow and adaptability of these populations of leishmaniasis vectors.

\section{ACKNOWLEDGMENTS}

To Ricardo Andrade Barata for technical help with the phlebotomine breeding and slide mounting, to the Núcleo de Medicina da Universidade do Ceará and to the Fundação Nacional de Saúde ( Coordenadorias Regionais Bahia and Ceará) for their assistance during field work.

\section{REFERENCES}

1. Antunes PCA, Coutinho JO. Nota sobre flebótomos sul-americanos. II Descrição de Flebotomus whitmani n.sp. e da armadura bucal de algumas espécies. Boletim de Biologia 4: 448-453, 1939.

2. Ausubel FM, BrentR, Kingston RE, Moore DD, Seidman JG, Smith JA, Struhl K. Short Protocols in Molecular Biology, $2^{\text {nd }}$ edition, John Wiley \& Sons, New York, 1992.

3. Azevedo ACR, Rangel EF. A study of sand fly species (Diptera: Psychodidae, Phlebotomine) in a focus of cutaneous leishmaniasis in the municipality of Baturité, Ceará, Brasil. Memórias do Instituto Oswaldo Cruz 86: 405-410, 1991.

4. Azevedo ACR, Rangel EF, Costa EM, David J, Vasconcelos AW, Lopes UG. Natural infection of Lutzomyia (Nyssomyia) whitmani (Antunes \& Coutinho, 1939) by Leishmania of the braziliensis complex in Baturité, Ceará State, Northeast Brazil. Memórias do Instituto Oswaldo Cruz 85: 251, 1990.

5. Caetano-Anolles G, Bassam BJ, Gresshoff PM. DNA amplification fingerprinting using very short arbitrary oligonucleotide primers. Biotechnology/Technology 9: 553-557, 1991.

6. Dias ES, Barata RA, Fortes-Dias CL, Brazil RP, Miranda JC, Brandão-Filho S, Linardi PM. Morphometric and phenetic studies of five geographical populations of Lutzomyia whitmani (Diptera, Psychodidae, Phlebotominae) in Brazil. Journal of Medical Entomology 36: 846-850, 1999.

7. Dice LR. Measures of the amount of ecological association between species. Ecology 26: 297-302, 1945.

8. Galati EAB, Nunes VLB, Dorval MEC, Oshiro ET, Cristaldo G, Espíndola MA, Rocha HC, Garcia WB. Estudo dos flebotomíneos (Diptera, Psychodidae) em área de leishmaniose tegumentar, no Estado do Mato Grosso do Sul, Brasil. Revista de Saúde Pública 30: 115-128, 1996.

9. Hashigushi Y, Chiller T, Inchausti A, Arias A, Kawabata M, Alexander JB. Phlebotomine sand fly species in Paraguay and their infection with Leishmania. Annals of Tropical Medicine and Parasitology 86: 175-180, 1992.

10. Hoch A, Ryan L, Vexanat JA, Cassia A, Rosa AC, Barretto AC. Isolation of Leishmania braziliensis braziliensis and other trypanosomatids from Phlebotominae (sic) in a mucocutaneous leishmaniasis endemic area, Bahia, Brazil. Memórias do Instituto Oswaldo Cruz 81: 62, 1986.

11. Ishikawa EAY, Ready PD, Souza AA, Day JC, Rangel EF, Davies CR, Shaw JJ. A mitochondrial DNA phylogeny indicates close relationships between populations of Lutzomyia whitmani (Diptera, Psychodidae, Phlebotominae) from the rain-forest regions of Amazonia and Northeast Brazil. Memórias do Instituto Oswaldo Cruz 94: 339-345, 1999.

12. Margonari CS, Dias-Fortes CL, Dias ES. Genetic variability in geographical populations of Lutzomyia whitmani elucidated by RAPD-PCR. Journal of Medical Entomology 41:187-192, 2004.

13. Mayrink W, Williams $P$, Coelho MV, Martins AV, Magalhães PA, Costa CA, Falcão AR, Melo MN, Falcão AL. Epidemiology of dermal leishmaniasis in the Rio Doce Valley, Minas Gerais, Brazil. Annals of Tropical Medicine and Parasitology 73: 123-137, 1979.

14. Modi GB, Tesh RB. A simple technique for mass rearing Lutzomyia longipalpis and Phlebotomus papatasi (Diptera, Psychodidae) in the laboratory. Journal of Medical Entomology 20: 568-569, 1983.

15. Passos VMA, Falcão AL, Marzochi MCA, Gontijo CMF, Dias ES, BarbosaSantos EGO, Guerra HL, Katz N. Epidemiological aspects of American cutaneous leishmaniasis in a periurban area of the metropolitan region of Belo Horizonte, Minas Gerais, Brazil. Memórias do Instituto Oswaldo Cruz 88: 103-110, 1993.

16. Pessoa SB, Coutinho JO. Infecção natural e experimental dos flebótomos pela Leishmania braziliensis no estado de São Paulo. Hospital 20: 25-35, 1941.

17. Queiroz RG, Vasconcelos IAB, Vasconcelos AW, Pessoa FAC, Sousa RN, David JR. Cutaneous leishmaniases in Ceará State in Northeastern Brazil: incrimination of Lutzomyia whitmani (Diptera: Psychodidae) as a vector of Leishmania braziliensis in Baturité municipality. American Journal of Tropical Medicine and Hygiene 50: 693-698, 1994.

18. Queiroz RG, Vasconcelos AW, Vasconcelos IAB, Sousa RN, Pessoa FAC, Alencar JE, David JR. Phlebotomine sand fly (Diptera: Psychodidae) fauna survey in an American cutaneous leishmaniasis (ACL) focus in Baturité, Ceará State, Northeast Brazil. Parasitologia 33 ( suppl 1) : 159-167, 1991.

19. Rangel EF, Lainson R, Souza AA, Azevedo ACR. Variation between geographical populations of Lutzomyia (Nyssomyia) whitmani (Antunes \& Coutinho, 1939) sensu lato (Diptera, Psychodidae, Phlebotominae) in Brazil. Memórias do Instituto Oswaldo Cruz 91: 43-50, 1996.

20. Ready PD, Day JC, Souza AA, Rangel EF, Davies CR. Mitochondrial DNA characterization of populations of Lutzomyia whitmani (Diptera, Psychodidae) incriminated in the peri-domestic and silvatic transmission of Leishmania species in Brazil. Bulletin of Entomological Research 87: 187-195, 1997.

21. Ready PD, Souza AA, Macario Rabelo JM, DayJC, Silveira FT, Campell-Lendrum D, Davies CR, Costa JML. Phylogenetic species and domesticity of Lutzomyia whitmani at the south-east boundary of Amazonian, Brazil. Transactions of the Royal Society of Tropical Medicine and Hygiene 92: 159-160, 1998.

22. Rohlf FJ. NTSys. Numerical taxonomy and multivariate analysis systems, version 2.0. Exeter Softwer, New York, 1990.

23. Santos FR, Pena SDJ, Epplin JT. Genetic and populational study of an Ylinked tetranucleotide repeat DNA polymorphism with a simple non-isotopic technique. Human Genetics 90: 655-656, 1993. 
24. Shannon RC. Methods for collecting and seeding mosquitoes in jungle yellow fever studies. Journal of Medical Entomology 19: 131-140, 1939.

25. Sneath PHA, Sokal RR. Numerical Taxonomy. Principles and Practice of Numerical Classification, WH Freeman, San Francisco, 1973.

26. Sudia WR, Chamberlain RW. Battery operated light-trap: an improved model. Mosquito News 22: 126-129, 1962.

27. Upton MS. Aqueus gum - Chloral slide mounting media; an historical review. Bulletin of Entomological Research 83: 267-274, 1993.
28. Welsh J, McClelland M. Fingerprinting genomes using PCR with arbitrary primers. Nucleic Acids Research 18: 7213-7218, 1990.

29. Williams JG, Kubelik AR, Livak KJ, Rafalski JA, Tingey SV. DNA polymorphisms amplified by arbitrary primers are useful as genetic markers. Nucleic Acids Research 18: 6531-6535, 1990.

30. Young DG, Duncan MA. Guide to the identification and geographic distribution of Lutzomyia sand flies in Mexico, the West Indies, Central and South America (Diptera, Psychodidae). Memories of the American Entomological Institute 54: 881, 1990. 